\title{
T-Cell Leukemia Homeobox Protein 3
}

National Cancer Institute

\section{Source}

National Cancer Institute. T-Cell Leukemia Homeobox Protein 3. NCI Thesaurus. Code C98101.

T-cell leukemia homeobox protein 3 ( $291 \mathrm{aa}, \sim 32 \mathrm{kDa}$ ) is encoded by the human TLX3 gene. This protein may be involved in transcriptional modulation. 